\title{
SEISMIC HAZARDS IN THE MEDITERRANEAN
}

by

\section{Christian C. Weber}

In the wake of the most recent disastrous earthquakes in Algeria and Italy, this article by the Secretary General of IUGS underscores the need for coordinated and multidisciplinary geoscientific effort to produce a seismotectonic map of the Mediterranean basin.

Two earthquakes in rapid succession have recently hit areas surrounding the Mediterranean: El Asnam in Algeria, on October 10, 1980 (magnitude 7.3, causing at least 3,500 deaths), and Acerno in Italy, on November 23, 1980 (magnitude 6.8 with about 3,000 deaths). These events have once again focussed attention on the geological instability of the Mediterranean basin. Although the number of earthquakes of high magnitude that occur in this part of the world is far lower than the number registered around the Pacific basin, the fact remains that, because of the population density of the Mediterranean area, movement of the plates has exacted a high toll.
While there is a fairly high degree of uncertainty surrounding the earthquakes that occurred during ancient times, seismic activity has resulted in over 350000 deaths since the 15 th century (Fig. 1). Many of these victims perished as a result of geological phenomena such as landslides induced by earthquake activity. For example, the Villach earthquake, which occurred in the Eastern Alps in 1348, caused a gigantic landslide, blocking the valley of the Gail River and inundating several communities.

The El Asnam quake shows spectacular surface faulting and illustrates some of the problems associated with seismo-

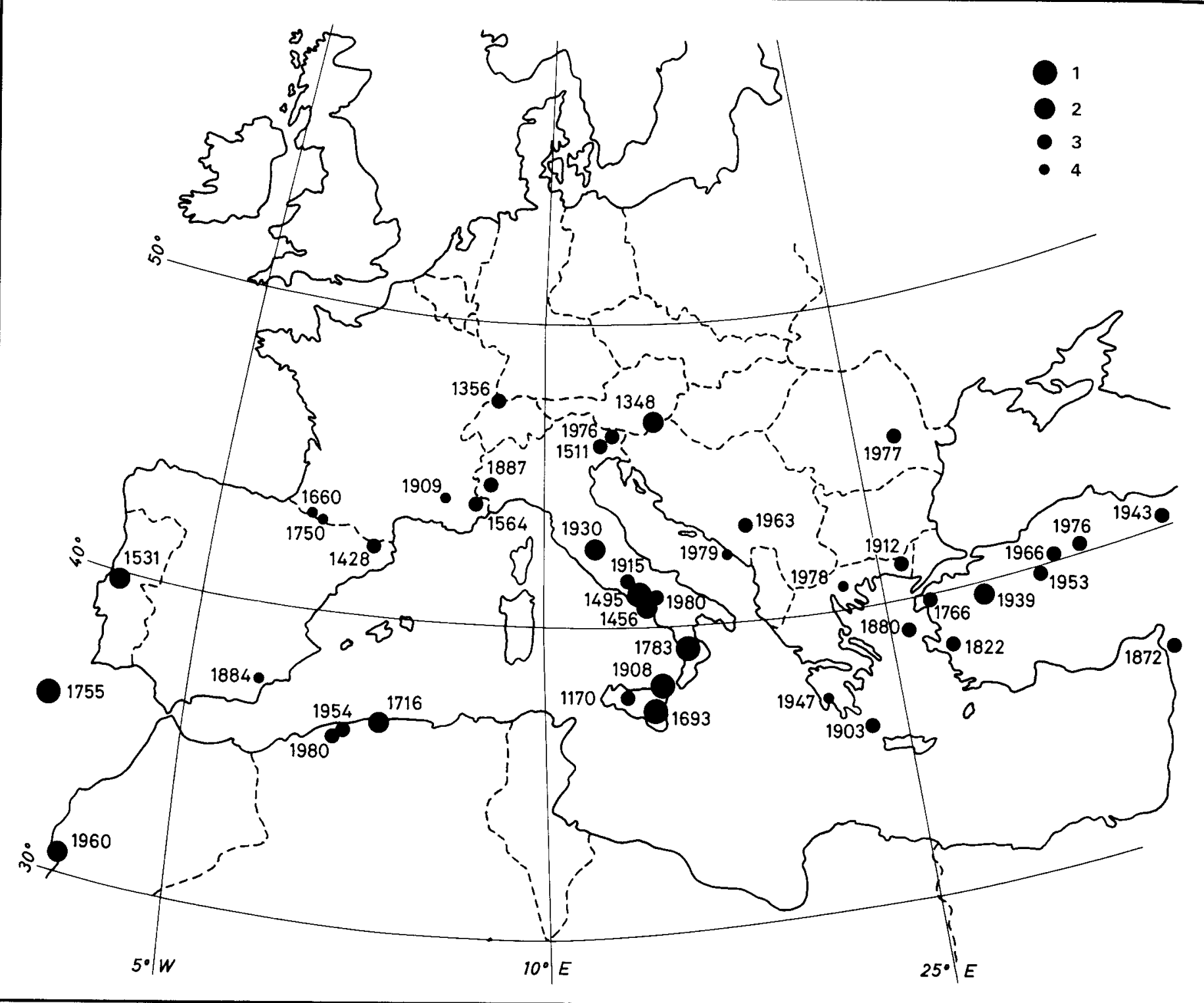

Figure 1. Main catastrophic earthquakes in the Mediterranean basin since the 15th century. 1: More than 50 000 dead, 2: More than 10000 dead, 3: More than 1000 dead, 4: Other large shocks. Location of certain events is approximate only, and estimates of the number of people killed in category 4 are unconfirmed. 


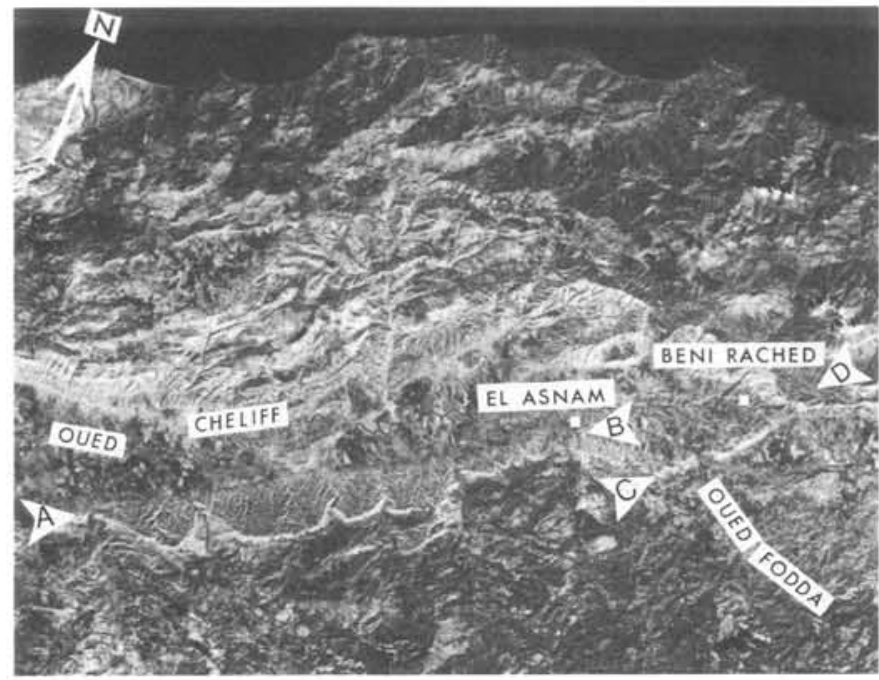

Figure 2. Landsat 2 image of the El Asnam region taken before the 1980 earthquake. From a composite colour print, September 23, 1977, 212 - 35, intensity levels $60-2000$.

tectonics. Satellite imagery (Fig. 2) has revealed a major NE -SW fault parallel to the Oued Chelif, bringing into contact Miocene marls and limestones with Pliocene-Pleistocene strata in the valley (A-B, Fig. 2). The cracks appearing on the surface on October 20, 1980 (Fig. 3) are located at the $\mathrm{NE}$ end of this major fault. Satellite images distinctly show a fault here that was not recognized in the field before the earthquake occurred (C-D, Fig. 2). The fault on the satellite image coincides with a well-mapped seismic faultbreak (Ambraseys, 1980; Ouesmer et al., 1980; Ouyed, 1980). An earlier destructive quake ( $E 1$ Asnam, 1954, then Orleansville) was associated with a group of faults aligned parallel with the Oued Chelif to the north (Beni Rached). They may correspond to a mass sliding of the Pliocene sandstones over the Miocene marls.

Geological observations carried out by different teams after the earthquake on October 20,1980, showed a main surface vertical offset of about 3 to $5 \mathrm{~m}$, usually along a reverse fault, with a sinistral horizontal component of 1.3 to $2.5 \mathrm{~m}$. Many aftershocks, recorded by the local seismic network set up immediately after the main shock (Ouyed, 1980), were mostly located on the $C D$ fault. Composite focal mechanisms indicate a general NE - SW compression, which agrees with the geological observations.

Epicentres of earthquakes with magnitudes greater than 5 have a distribution pattern that makes it difficult to identify the boundaries of the plates. Of course, it is possible, as some authors have done, to identify a great number of smaller plates, the boundaries of which correspond to the most obvious alignments of epicentres. However, a more realistic approach involves taking into account the dynamics of these phenomena, which are essentially linked with the displacement of Africa relative to the position of Eurasia (Fig. 4). Moreover, very detailed studies of the structural geology of the area make it possible to define the successive deformations, resulting from either tension or compression, which have determined surface features since the Mesozoic era.

In the most active regions, such as the Baetic Cordillera and the Aegean Arc, neotectonic observations enable us to reconstruct the deformation ellipses (Le Pichon and Angelier, 1979), the data for which constitutes a useful complement to the data for the activity at the seismic focii. In order to make as much use as possible of this information, P. Tapponnier (1977) proposed a pattern of tectonic development by rupture-plastic deformation in the form of wedging and crushing for the Mediterranean alpine system (Fig. 5). As the continents collide, the promontories of Africa act as wedges to change the form of the Eurasian plate, expelling its lithosphere laterally along lines of shear. In other cases, EPISODES, Vol. 1981, No. 1 .

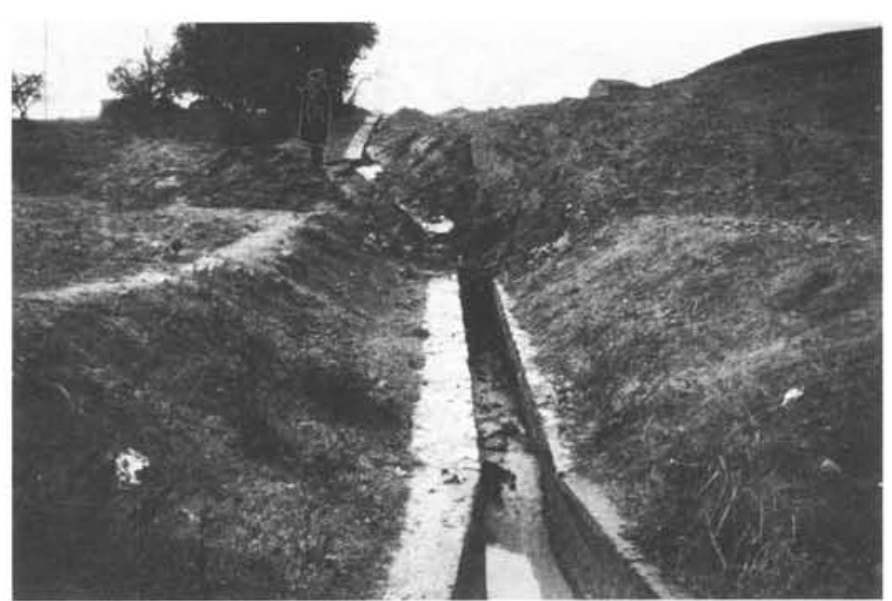

Figure 3. A main seismic fault. The displacement, both vertical and sinistral, is clearly shown by the water channel.

continental crushing occurs when the shape of the promontory, which is part of the African continent, is changed through contact with Eurasia. As Figure 5 shows, situations which combine both effects exist.

This pattern of tectonic development for the Mediterranean, which may yet be further refined, has the advantage of effectively explaining existing zones of intracontinental deformation. Clearly, only the earthquakes that occur in the Aegean and the Tyrrhenian Arcs and the Vrancei Mountain area of Rumania can be associated with subduction zones. Most earthquake zones around the perimeter of the Mediterranean correspond to recurrent intra-plate fracturing, and most of these zones first developed between Eocene and Miocene time. Recent experimental explosion seismology data reveals the complexity of the crustal structure and confirms the existence of major fractures in the continental lithosphere.

Although a few doors have been opened, this certainly does not mean that geologists and geophysicists now have sufficient knowledge of the spatial and temporal distribution of earthquakes in the Mediterranean basin, or that they can effectively predict an imminent earthquake: witness the earthquake in Campania on November 23, 1980. An article by M. Caputo, V. Keilis-Borok et al. (1980) presents a study of the dangerous earthquake zones in Italy based on an algorithm for pattern recognition developed by Russian mathematicians. This study involved the preparation of sets of

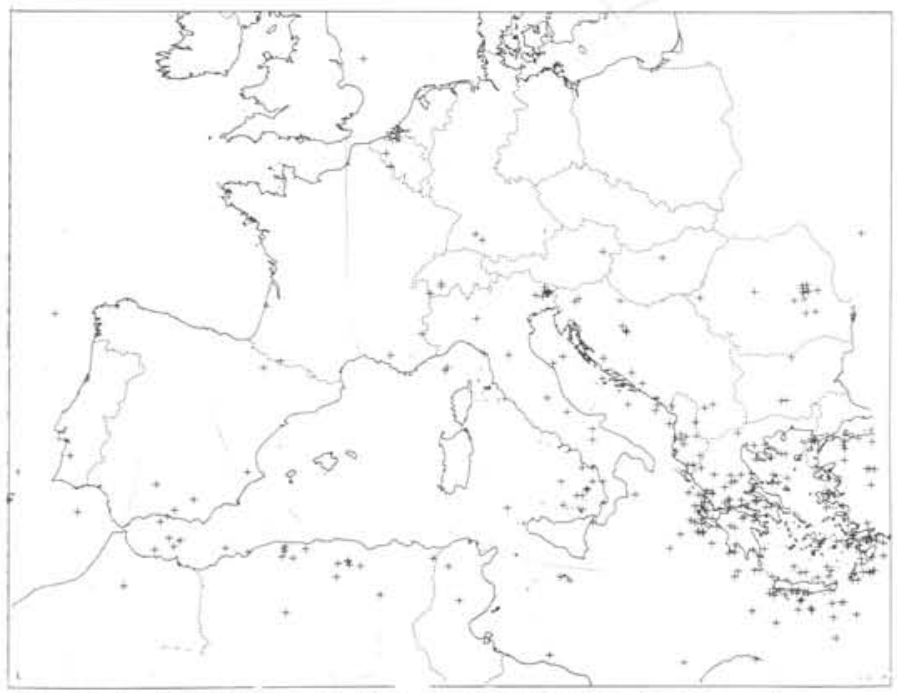

Figure 4. Seismicity of the Mediterranean basin; epicenters of magnitude greater than 5, for the period 1905 - 1977 (from Vogt and Weber, 1979). 


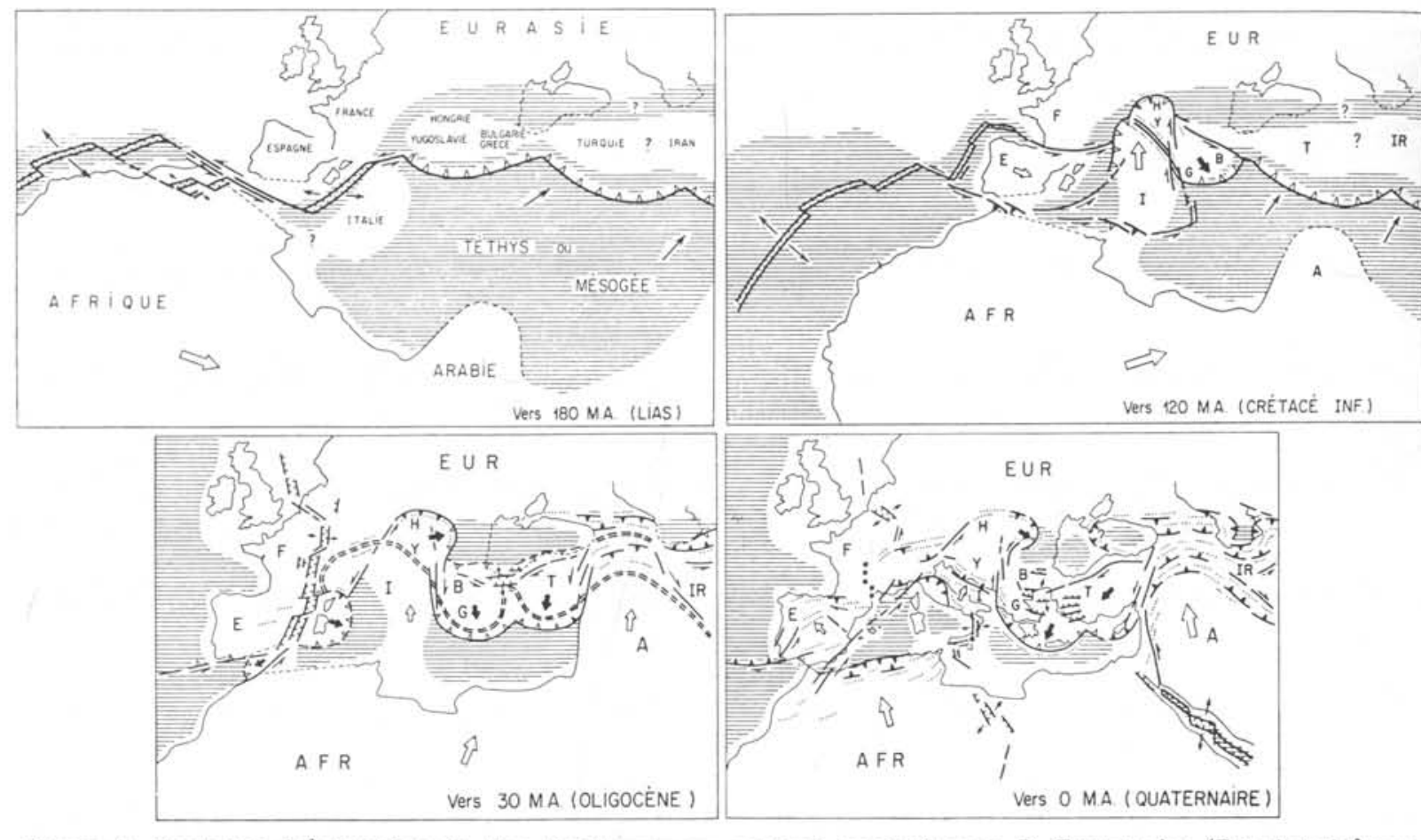

Figure 5. Tectonic deformations in the Mediterranean regions, according to P. Tapponnier (Reprinted from Tapponnier, 1977).

varied criteria (essentially geomorphological in nature), which describe lineament intersections and can be used to differentiate between those that are dangerous and those that are not. The study focussed on 173 intersections and singled out 34 as dangerous in the "earthquake future" experiment. The epicentre of the November 23, 1980 earthquake coincided precisely with one of these intersections, between a transverse and a longitudinal lineament. Although this method certainly represents a step forward, at present it would be impossible to monitor the 34 zones categorized as dangerous.

The earthquake in Campania draws attention to the necessity of improving our understanding of the earthquake zones in Mediterranean countries. The method described above is not intended to provide a definitive explanation of the observed earthquake distribution pattern. It uses an essentially mathematical line of reasoning to differentiate between two categories of areas. Only a global approach will enable scientists to improve their understanding of the seismic risk involved.

It is essential, first of all, to review the documents in the archives of those countries with long recorded histories and to rid these "classic" files of the errors and approximations

\section{References} quakes: Nature, v. 232, no. 3310 , p.375-379.
Czech. Acad. Sci., Prague, 218 p.

Ambraseys, N.N. 1980, The El Asnam earthquake of 10 Le Pichon, X., and Angelier, J., 1979, The Hellenic arc and October 1980: Unesco Report DC/RP/251570

Biju-Duval, B., Dercourt, J., and Le Pichon, X., 1977, From the Tethys ocean to the Mediterranean seas, in Structura history of the Mediterranean basins: Ed. Tectnip, Paris, France, p. 143-164.

Caputo, M., Keilis-Borok, V., et al., 1980, Pattern recognition of earthquake-prone areas in Italy: Physics of the Earth and Planetary Interiors, v. 21 , no. 4, p. 305-320.

Fourniguet, J., Vogt, J., and Weber, C., 1981, Seismicity and recent crustal movements in France: Tectonophysics, $v$, $195-216$.

Karnik, V., 1969, Seismicity of the European area, part 1: D. Reidel Publ. Co., Dordrecht, $364 \mathrm{p}$. trench system: a key to the neotectonic evolution of the eastern Mediterranean area: Tectonophysics, v. 60 , no. $1-2$, p. 1-42.

Ousmer, N., Briedj, M., Amokrane, M., Benzerga, Z., Djender, M., Bedouhene, F., Benrabah, M., Becis Becis, B., and Champelev, A., 1980, Le tremblement de terre d'El AsAlgérien de litndustrie Lourde, sous-direction de ta géologie, $26 \mathrm{p}$.

Ouyed, M.. Meghraoui, M., Antenor-Habazac, C., Bourezg, S., Cisternas, A., Dorel, J., Fréchet, J., Frogneux, M., Hatzfeld, D., and Philip, H., 1980, Le séisme d'El Asnam du IO octobre 1980, premiers résultats sismologiques et tec-
toniques: C.R. Acad. Sci. Paris, v. 291, séric D., p. 921 - that they may contain. Though painstaking, the task has ations require groundwork in the field of geology (very little earthquake, for example). The seismotectonic map represents a synthesis of all the geophysical and geological data,

first detailed seismotectonic mapping conducted in EurSkopje earthquake Balkans and was undertaken following the UNDRO (United Nations Disaster Relief Office) and set in motion a major and useful international cooperative effort. imilar project, and others are in progress in Spain and Algeria. The two earthquakes of 1980 have hastened the development of an awareness that a coordinated interof understanding of the problem of seismogenesis in the Mediterranean basin.

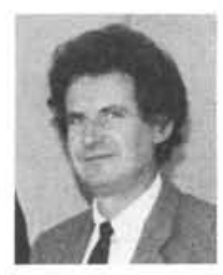

EPISODES, Vol. 1981, No. 1.
ABOUT THE AUTHOR: Secretary General of IUGS, Christian C. Weber is Assistant Director of the Geological Survey, BRGM, France. His prime research interests are the distribution and hazard assessment of earthquakes and the geological interpretation of magnetic anomalies. Chairman of IUGS's Working Group on Magnetic Anomalies, Dr. Weber lectures at the Université Paris VI and the Institut Français du Pétrole.
924.

Ritsema, A.R., 1979, Catastrophic earthquakes in the European Area: Tectonophysics, v. 53, no, 3-4, p. 155-158.

Tapponnier, P., 1977, Evolution tectonique du système alpin en Méditerranée: poinçonnement et écrasement rigideplastique: Bull. Soc. Géol. France, 7, v. XIX, no. 3, P.

vogt, J., et al., 1981, Carte sismotectonique de la France: Mém. BRGM no, 111, in press.

Vogt, J., and Weber, C., 1979, Les grands traits de la sismicité en France, in Vogt, J., (ed.), Les tremblements de terre en France: Mem. BRGM no. 96, p. 205-212.

Weber, C., and Courtot, P., 1978, Le séisme du Frioul, Italie, 6 mai 1976, dans son contexte sismotectonique: Revue de Géogr. Phys. et de Géol. Dynam., v. XX, fasc. 3, p. 247. 